\title{
MEDICAL ETHICS AND THE POLITICS OF THE SOUTH AFRICAN HIV/AIDS EPIDEMIC
}

\author{
Dave Spencer \\ fohannesburg, South Africa
}

'Who among us shall dwell with the devouring fire? Who among us shall dwell with everlasting burnings?' He who walks righteously and speaks uprightly. He who despises the gain of oppression, who gestures with his hands refusing bribes. Who stops his ears from hearing of bloodshed and shuts his eyes from seeing evil."

Politics has been defined as the 'art and science of government' and ethics as 'moral principles, the science of morals in human conduct, rules of conduct'., ${ }^{3}$ The reader would know politics by its public face - its leaders, their words, their actions: 'levelling the playing fields', 'quiet diplomacy', 'kill the farmer, kill the boer', 'shifting the goal posts', 'redressing the imbalances', 'playing the race card.' Ethical issues in health are familiar too: triaging survivors, prioritising limited budgets, maintaining confidentiality, obtaining informed consent, deciding upon ventilator/dialysis access, euthanasia and embryo research. Making choices has never been easy.

Writing from prison in 1945, Bonhoeffer commented upon ethics: 'Rarely has any generation shown so little interest in any kind of theoretical or systematic ethics. Our period of history is oppressed by an abundance of ethical problems. Today, there are once more villains and saints. These emerge from the primeval depths to open the infernal or divine abyss and allow us to see briefly into mysteries of which we had never dreamed. What is worse than doing evil is being evil. It is worse for a liar to tell the truth than for a lover of the truth to lie. A falling away is of infinitely greater weight than a falling down. One is distressed by the failure of reasonable people to perceive the depths of evil or the depths of the holy. With the best of intentions they believe that a little reason will clamp together the parting timbers of their house... ${ }^{14}$

Twelve years have passed since the establishment of South Africa's new democracy. Over this period the country's HIV prevalence has grown from 3\% to 11 - 17\%. Maternal prevalence rates and those of several provinces are higher. ${ }^{5,6} \mathrm{~A}$ recent report detailing the HIV prevalence among 17088 South African teachers indicated that $12.7 \%$ were infected and that 52\% of these had CD4 cell counts below $350 \mu \mathrm{l}$ and 22\% counts below 200/ $\mu$ l. $^{7}$ Most governments are ill prepared to cope with disasters of the magnitude of the AIDS epidemic. The new South African government has fortunately enjoyed the support of the international community and has had two decades of scientific knowledge upon which to draw. With fewer resources, Uganda reduced HIV prevalence from over $20 \%$ in 1993 to 5 - 8\% currently. Thailand, like South Africa a 'middle-income' country, has maintained its $3 \%$ prevalence over the same period. ${ }^{8-10}$ Despite the goodwill of scientists locally and abroad, the South African government has frequently chosen to follow an independent route with regard to public discussion and the management of the epidemic.

Dissidents who dispute the science of HIV have openly advised government and continue to do so. ${ }^{11}{ }^{12} \mathrm{Mr}$ Mbeki has at times based his remarks upon insights from the Internet, a source of unregulated data, opinion and bias. ${ }^{12,13}$ Cabinet advocacy for the play 'Sarafina II' and the so-called AIDS cure, virodene, was premature and inappropriate: 'Instead of emerging victorious with a new African miracle cure, the government's reputation was harmed by the strong aroma of sleaze which permeated the virodene episode and by the fact that it ignored scientific checks and balances. Instead of accepting the recommendations of the Medicines Control Council (MCC), the government undermined the body by removing the chairperson and replacing him and others with more compliant members.'13

Herbs, vegetables, so-called 'immune boosters', various 'diets' and vitamin concoctions have been advanced as benefiting the infected. ${ }^{14,15}$ Evidence-based support for these assertions is largely absent, anecdotal, speculative or simply misinformation. Scientific data promoting the use of vitamins and trace elements in the HIV patient is limited. Where deemed to be indicated, vitamins and trace elements are not viewed as alternatives to the antiretroviral (ARV) drugs. ${ }^{16,17}$ Nutritionists and researchers agree that patients require access to healthy diets, and that where nutrition is needed this ought to be provided in the form of food. ${ }^{18,19}$ Support by public figures of homespun 'remedies' has led to general confusion and in some cases to patients refusing life-saving therapy with consequent loss of life..$^{20}$

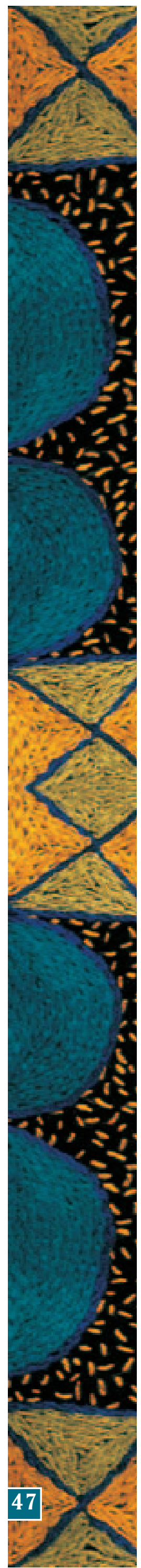




\section{ETHICS IN THE CONTEXT OF GOVERNMENT}

Moral principles should govern behaviour in government and in health care. We use ethical language when addressing political and health matters: 'primum non nocere' (first do no harm), autonomy, beneficence, non-maleficence, justice and futility, and we contrast altruism with self-interest. The application of these ideas to society underlies the day-to-day running of government: utilitarianism - 'the greatest happiness of the greatest number' (Jeremy Bentham, 17481832), human rights (individual v. community rights), communitarianism - the building of a good and just society. 38,39

The ANC government of 1994 inherited an imperfect health care system. ${ }^{30}$ Regional health has deteriorated for years: life expectancy in South Africa has fallen for the past 40 years and current levels are below those of $1960{ }^{40}$ The AIDS epidemic has played a part in this, but one must also acknowledge the persistence of poverty, inadequate education, poor rural and urban living conditions and the fractured health infrastructure that grew out of the apartheid system. 'History', says Roberts, 'has many examples of people who sought to impose their vision of a good society by force - from the Crusades to the Khymer Rouge to the Taliban. Moving from coercion to coexistence, tolerance, and mutual learning requires a degree of openness that many find inconsistent with the certainty of their own vision.38

\section{DO GOVERNMENTS HARM THE HEALTH} OF THEIR CITIZENS?

Sadly, many do. Living in South Africa before 1994 ensured unequal access to health care. We live with this legacy. 'The Nazi doctors made hell', is Elie Wiesel's commentary on life in Europe during the 1930s and 1940s. ${ }^{41}$ Lenin wrote of 'purging the Russian soil of all kinds of harmful insects.' ${ }^{\text {'2 }}$ Mao, according to the authors of a recent biography, 'was responsible for well over 70 million deaths in peacetime'.43 Zimbabwe: 'its ambulance fleet includes nine ox-drawn carts, introduced in July (2004) as part of the struggle against climbing maternal mortality rates. Life expectancy at birth according to the UNDP Human Development Report for 2004, is 33.9 years. ${ }^{\prime 4}$ South Africa: 'Between 1995 and 2000 the public health sector in the Western Cape was downsized by 3601 hospital beds (24.4\%) and by 9282 health and support personnel (27.9\%), while the local population grew by $8 \%$.' Benatar continues, 'Public tertiary health services have been severely eroded... The failure of the (South African) government to promote a prevention campaign over the past decade and an initial focus on ineffective treatments have contributed to sustained and pervasive denial of the existence of the HIV pandemic as well as perpetuation of the stigma associated with HIV and AIDS. ${ }^{130}$

Politicians are salaried public servants and are answerable to the community they serve. Our government has been reelected twice and tasked with the provision of equable care to all its citizens - including those who carry the HI virus. 'Unemployment insurance, old age pensions, workmen's liability acts and other similar legislation represent the effort of political society to mitigate the inequalities which are created by the process of economic development ... The economic system heaps up profits in the hands of the owners of property and the state uses the power of taxation to reduce these profits and to assist the worker...45 But as Niebuhr observes, even democratically elected governments have their own agendas: 'The creeds and institutions of democracy have never become fully divorced from the special interests of the commercial classes who conceived and developed them. ${ }^{146}$ 1994 ushered into power those who were once the objects of the abuse of power. Has such a perspective resulted in better government? Is the altruism demanded of the newly qualified health worker who is obliged to complete community service matched by a similar altruism of the politician? How ought the South African public to view 'floor-crossing', the failure of municipalities to deliver basic services, unspent budgets, scandals - 'armsgate', 'oilgate', 'travelgate'? Is this altruism or self-service?

Who audits government? Where political opposition is weak most governments are left to audit themselves. 'The moral attitudes of the dominant and privileged classes are characterized by self-deception and hypocrisy... The most common form of hypocrisy among the privileged classes is to assume that their privileges are the just payments with which society rewards specially useful and meritorious functions. ${ }^{177}$ Governments and most human beings lack the moral clarity to judge themselves without bias.

\section{WHAT OF THE HEALTH WORKERS THEMSELVES?}

A recent review of nursing care in two Eastern Cape hospitals reported serious irregularities. The nurses and doctors had been trained in the management of severe malnutrition in children. Their performance was studied from April 2000 to April 2001. The authors comment: 'Despite the shortcomings in care, most aspects of the World Health Organization (WHO) guidelines were feasible, even with scarce resources ... The researchers visited each hospital about 6 times per month. Visits were unannounced and unobtrusive. A high proportion of deaths were due to doctor error ... but weaknesses in support and supervision from local and central management gave rise to a lax environment, exemplified by nurses fabricating pulse and respiration rates and some night nurses giving antibiotics hours ahead of schedule. ${ }^{\prime 8}$

The training of health workers is not enough to ensure good medical care. Researchers note that 'for decades it was assumed that poor performance was due to a lack of knowledge and skill. The use of oral rehydration salts greatly increased during the 1980s and 1990s. However after more than 2000 training courses on the management of diarrhoea and the provision of supervision from 1988-93 in more than 120 countries, the median percentage of children correctly rehydrated by health workers as assessed in 22 surveys, was only 20\%.49 These researchers draw the conclusion that poor 
health worker practices contribute to the low use of health facilities by vulnerable populations. Among reasons cited by poor Kenyans for failure to access health facilities were 'lack of money' and 'the belief that hospital staff have insufficient understanding of and tolerance for the patient's social and economic circumstances and language, and that facilities and drugs might be inadequate to assist their sick child. ${ }^{50}$

This perception seems to be held by the South African public too: 'Ms N.M. had been at the Helen Joseph Hospital in Johannesburg, since 6.30am. She had resigned herself to spending the day at the hospital. "I travel from Soweto to come here and get my pills because the service is better than at Baragwanath. There, the nurses scold us and will not help you if you don't have money to pay. The nurses go out for lunch and tea breaks, leaving us sitting here and when they come back they shout at us. I don't know why. And there is nothing we can do because we are poor. ${ }^{m 151}$ The South African Minister of Health after a recent visit to Chris Hani Baragwanath Hospital is quoted as saying, 'judging by what I have seen, I would not encourage people to use public health facilities' ${ }^{52}$

\section{WHAT OUGHT TO BE DONE?}

What ought to be done to respond to the ethical and political issues surrounding the provision of care to the HIV-infected community of South Africa?

\section{ACTIVISM}

AIDS activism in North America and Europe resulted in an expanded access to ARVs, price reduction and the promotion of research: 'Decisions about the allocation of resources are inherently political and are thus amenable to effective lobbying'.53 Locally, the Treatment Action Campaign has garnered support from city and township dwellers and rural communities. In so doing it has become a legitimate voice of the people. ${ }^{54,55}$ How might the ordinary health worker respond to perceived inadequacies or injustice? Withholding their vote or voting for an alternative party, drafting and supporting petitions, joining NGOs and activist groups or forming new groups - it was particularly the mass movements of the 1980s that led to the demise of the apartheid regime. There are issues that need to be addressed: speeding the process of new drug registration, enhancing access of indigent patients to ARVs, addressing the low morale of health workers in ARV rollout programmes, assisting in projects that aim to build the numbers and competency of staff employed in rollout centres. Those health care facilities that persist in rendering inadequate service must be identified and pressured to change. Corrupt health workers and disinterested officials must be weeded out of the system. The promises of government and local authorities must be matched by performance. Allocated budgets must be spent. Concerned bodies such as the HIV Clinicians Society might consider closer links with activist groups and networking with the Trade Union Movement and with grassroots communities across the country.

\section{DEALING WITH DENIAL}

Preventive strategies were defined decades ago. Universally acceptable treatment guidelines have been in the public domain for many years. Yet both transmission and mortality continue to increase. Denial has fed this situation. 'AIDS is here to stay. It is like the day after Hiroshima (or after 9/11!). The world has changed and will never be the same again. The new virus will be a fact of life for our children's children; much can be done to moderate its force, but it cannot be made to disappear. ${ }^{156}$ Asked about the value of garlic, olive oil, etc., the health minister commented, 'no one said these diets cure HIV. However they boost the immune system. I have met over 100 patients who 'got-up-and-walked' after following this dietary advice. ${ }^{157,20} \mathrm{~A}$ truthful understanding of the epidemic has been scuttled by a belief in non-science, folklore and dissident opinions. Where truth is muddied and denied, society will not find solutions to the epidemic. Has this denial been deliberate? Do the politicians really believe what they say? Are politicians able to envision alternatives to the situations they are tasked to deal with? Can they work outside the box of their own value system and world view? 'It is the vocation of the prophet to keep alive the ministry of imagination, to keep on conjuring and proposing alternative futures. ${ }^{15}$ Few would credit the religious community of our day as having the status to provide such leadership. Prophets appear largely to have passed into the realm of antiquity and obscurity. Nevertheless we need them. 'Any justice which is only justice soon degenerates into something less than justice. It must be saved by something which is more than justice. The realistic wisdom of the statesman is reduced to foolishness if it is not under the influence of the moral seer. ${ }^{159}$ Politicians need ethics and the ethical scholar to guide them. Opposition to apartheid drew strength from tough religious people and those communities that refused to accept the status quo. We need such people today. The issue of denial needs to be faced both at the level of government and by the community. Infection with the HIV virus is perceived as shameful and evokes disgust, revulsion and rejection by many in the community. Exposure in the early days of the epidemic led to censure, harassment and in some cases the death of the infected person. ${ }^{60}$ Only openness and honesty will deal with these inappropriate attitudes. Several political leaders have spoken of their sorrow concerning the loss of family members from this disease. But those who are themselves infected and enjoy prominence within our society need to become role models for society: seen to be taking medication, living well, dealing with life in a humble but challenging manner. We lack these heroes.

\section{WHY DO GOVERNMENTS FAIL TO CONFRONT AIDS ADEQUATELY?}

Sexual transmission is the dominant vehicle of spread in Africa. 'Safe sex' means abstinence, or being persistently faithful to one's spouse/partner, and using condoms to prevent exposure to body fluids. A core responsibility of government is to ensure that those most likely to spread disease adopt preventive behaviour. ${ }^{61}$ Recent data suggest that some young people influenced by the 'loveLife' campaign 
may be altering lifestyles. However, there is little evidence that viral transmission in the southern African region as a whole is diminishing. Can a nation or a continent change its culture? At the core of this epidemic is the vulnerability of our youth, particularly adolescent girls between the ages of 15 and 19 years. The HIV prevalence among this group far outnumbers that of boys of the same age. Older males transmit the virus to these teenagers. This culture of abuse clearly needs to change. ${ }^{62,63}$ But some customs are part of everyday life in Africa: long engagement periods necessitated by inflated bride prices, premarital sex to confirm fertility, conjugal rights of widows to males within the extended family or tribe. To these add poverty and sex for money, poor acceptability of condoms, single-parent homes, fathers and husbands who work long distances from their families and seldom return home. If this epidemic will be heard, it is saying that society has to change in significant ways. This perhaps is the central 'meaning' of this epidemic. What politician has shown any determination to confront this Goliath? 'The man with a conscience fights a lonely battle against overwhelming forces of inescapable situations which demand decisions. Evil comes upon him in countless respectable and seductive guises so that his conscience becomes timid and unsure of itself, till in the end he is satisfied if instead of a clear conscience he has a salved one, and lies to his own conscience in order to avoid despair. A man whose only support is his conscience can never understand that a bad conscience may be healthier and stronger than a conscience which is deceived.64 Ron Bayer: 'There are no simple answers that address the needs both for trust and candor in intimate relationships and for security in the era of AIDS. Systematic behavioral research is essential, as is searching inquiry into the ethical and psychological underpinnings of intimate relationships. Nonetheless, these questions make it clear that matters of sexual ethics are not moralistic diversions. They are at the heart of AIDS prevention. ${ }^{65}$

Case isolation, quarantine, contact identification, notification and the provision of treatment underpin the effective public health response to a serious communicable disease. ${ }^{8}$ With regard to the prevention of HIV, South Africa took its lead from Europe and North America where so-called HIV 'exceptionalism' had taken root. ${ }^{66}$ Notification and identification were deemed to be an infringement of the individual's rights and likely to drive the epidemic underground. Perhaps the memory of the 'Pass Laws' and the abuse of personal freedom prompted this position, or the fact that in its earliest days the South African epidemic was focused on the white, middle-class gay community and thus not unlike that of Europe and the USA. Without notification, the South African government has been able to query prevalence data and contradict research findings. ${ }^{67,68}$ 'Governments', say Ainsworth and Teokul, 'will do those things that are not viewed as controversial and that can be expected to have widespread support.' ${ }^{161}$ Would the 'public health' model of disease prevention be appropriate to South Africa? Can a government police its entire population? Cuba's approach has been dramatically successful: the HIV prevalence in Cuba is currently $0.03 \%$, only 4000 infected in a population of more than 13 million. ${ }^{69,70}$ It took a traditional public health approach incorporating isolation, quarantine and notification of exposed partners. How would one quarantine 6 million infected South Africans?

Is it not time to end this HIV exceptionalism? Several experts suggest that it may be. $8,66,71$ De Kock argues for performing mandatory, voluntary and routine testing and testing where patients present with specific HIV-related illnesses such as TB and sexually transmitted diseases (STDs). It is stressed that such testing must be done in an open manner while maintaining strict confidentiality. In support of this approach he argues, 'What if the HIV prevalence were $30 \%$ in Geneva or New York?'8 He notes that AIDS awareness is now huge in most of sub-Saharan Africa and that evidence of benefit from extensive pre-test counselling for HIV in this region 'is lacking'. Other researchers remind their readers that the political costs of promoting a public health approach include 'offending both sides of the political establishment'. They continue, 'Controlling epidemics is a fundamental responsibility of government, working in concert with physicians, patients and communities. Until we implement prevention programs with proven efficacy more widely, make voluntary screening and linkage to care a normal part of medical care and expand screening in community settings, and improve treatment, risk reduction, monitoring, and partner notification, we will continue to miss opportunities to reduce the spread of HIV infection. ${ }^{.71}$ While the South African government and society fail to address the underlying cultural and ethical issues that orbit around this epidemic there is little likelihood that we in South Africa will follow these recommendations.

What of the health worker whose conduct is unprofessional? How does one change the low morale of our nurses and doctors? Denial and disinformation - untruth - have perpetuated the spirit of futility that has characterized much of the government's response to this epidemic. Health workers, we are told, are 'burnt-out and demoralised'. ${ }^{2}$ But the epidemic is not yet over. Indeed the virus is likely to remain with us for many generations. Arthur Frank speaks of the rebuilding of Czech society in the 1990s: 'Vaclav Havel realized that the success of any institutional reform in postcommunist Czechoslovakia depended on individual moral work. ${ }^{173}$ The principles are no different in Africa. 'Individual moral work.' Ethics and the practice of health care are inseparable. Ethics and the practice of good governance are inseparable. The control of the epidemic with vaccines and various 'magic bullets' are unrealistic dreams at this time. A cure is not around the corner. Hard work and difficult choices lie ahead. Inadequacies in the prevention of transmission need to be reviewed. The debate over appropriate public health strategies requires further thought. Cultural mores and norms that do the nation a disservice must be openly debated and change embraced where appropriate. Clear-thinking leadership, truthfulness and humility on the part of our politicians and goodwill on the part of our scientists may help to bring the country out of the dark tunnel it is in. The 
plundering of this nation's life will only be halted when citizens and government listen to the lessons the epidemic is teaching.

REFERENCES

1. Isaiah 33:14,15. The Holy Bible, New King James Version.

2. Politics. In: Concise Oxford Dictionary. 8th ed. Oxford: Oxford University Press, 1990: 922.

3. Ethics. In: Concise Oxford Dictionary. 8th ed. Oxford: Oxford University Press, 1990: 401.

4. Bonhoeffer D. Ethics. SCM Press, 1955: 46, 47. (Originally published in German in 1949.)

5. Dorrington RE, Bradshaw D, Johnson L, Budlender D. The Demographic Impact of HIV/AIDS in South Africa. National Indicators for 2004. Cape Town: Centre for Actuarial Research, South African Medical Research Council and Actuarial Society of South Africa, 2004

6. Nelson Mandela Foundation/ Human Science Research Council. South African National HIV Prevalence, Behavioural Risks and Mass Media Household Survey 2002. Cape Town: Human Sciences Research Council, 2002.

7. Rehle T, Shisana O. Estimates of eligibility for antiretroviral treatment (ART) and projected ART impact on AIDS mortality among South African educators. J Social Aspects HIV/AIDS 2005; 2 (Nov) 304-310,

8. De Cock KM, Mbori-Ngacha D, Marum E. Shadow on the continent: public health and HIV/AIDS in Africa in the 21st century. Lancet 2002; 360: 67-72.

9. Parkhurst JO. The Ugandan success story? Evidence and claims of HIV-1 intervention. Lancet 2002; 360: 78-80.

10. 2004 Report on the Gobal AIDS epidemic: 4th Global Report Geneva: Joint United Nations Programme on HIV/AIDS (UNAIDS), 2004: 22-58.

11. Khan T. Dissidents address the South African National Health Council. Business Day 2005; 19 October.

12. Baleta A. Questioning of HIV theory causes dismay in South Africa (Editorial). Lancet 2000; 355: 1167 .

13. Nattrass N. The Moral Economy of AIDS in South Africa. Cape Town: Cambridge University Press, 2004: 47-49.

14. Smetherham J-A. Cape Times 2004; 27 February (quoted from an article dealing with the alleged support of the minister of health for dietary interventions in the management of HIV/AIDS.)

15. Morris K. Treating HIV in South Africa - a tale of two systems. Lancet 2001; 357: 1190.

16. World Health Organization, Department of Nutrition for Health and Development. Executive Summary of a Scientific Review. Consultation on Nutrition and HIV/AIDS in Africa: Evidence, lessons and recommendation for action. Durban, South Africa, 10-13 April 2005, pp 1-16.

17. Tang AM, Lanzillotti J, Hendricks $K$, et al. Micronutrients: current issues for HIV care providers. AIDS 2005, pp. 19: 847-861.

18. Souba WW. Nutritional support. N Engl J Med. 1997; 336: 41-48

19. Grinspoon S, Mulligan K. The role of nutritional support in the HIV patient. Clin Infect Dis 2003; 36. Suppl 2, S69-S78.

20. McGregor L. Khabzela, The Life and Times of a South African. Johannesburg: Jacana Media, 2005.

21. Médecins Sans Frontières. AIDS triple therapy for less than $\$ 1$ per day. www.msf.org/content/page.cfm?articleid=994F25CO-B3F7-415D943186A5D0F6E1BA (accessed 12 February 2002).

22. Creese $A$, Floyd $K$, Alban $A$, Guiness $L$. Cost-effectiveness of HIV/AIDS interventions in Africa: a systematic review of the evidence. Lancet 2002; 359: 1635-1642.

23. Severe $P$, Leger $P$, Charles $M$, et al. Antiretroviral therapy in a thousand patients with AIDS in Haiti. N Engl J Med 2005; 353: 2325-2334.

24. Cooper ER, Charurat N, Mofenson L. et al. Combination antiretroviral strategies for the treatment of pregnant HIV-infected women and prevention of perinatal HIV-1 transmission. J Acquir Immune Defic Syndr 2002; 29: 484-494.

25. Editorial. Hope for South Africa - at last. Lancet 2003; 362: 501.

26. Wainberg MA. Generic HIV drugs - enlightened policy for global health. N Engl J Med 2005; 352: 747-750.

27. Sterne $L A$, Hernana $M A$, Ledergerber $B$, et al. Long-term effetiveness of potent antiretroviral therapy in preventing AIDS and death: a prospective cohort study. Lancet 2005; 366: 378-384.

28. Baleta A. S African president criticized for lack of focus on AIDS. Lancet 2004; 363: 541.

29. Kapp C. HIV overshadows South African health advances. Lancet 2004; 363: 1202-1203.

30. Benatar SR. Health care reform and the crisis of HIV and AIDS in South Africa. N Engl J Med 2004: 351: 81-92

31. Singh JA. Health research and human right in South Africa. Lancet 2004; 363: 1393.
32. Taitz L. A dingy start to another dingy AIDS initiative. Sunday Times 2000; 28 February.

33. Bateman C. SA's doctors take to the streets. S Afr Med J 2004; 94: 144-146.

34. Morris K. Aids activists win battle, drug war continues. Lancet 2000; 356: 1994

35. Abdool Karim Q. HIV treatment in South Africa: overcoming impediments to get started. Lancet 2004; 363: 1394.

36. Baleta A. S Africa soaks up pressure to change HIV/AIDS policy. Lancet 2002; 360: 467.

37. Baleta A. South Africa's stance on nevirapine on trial. Lancet 2001; 358: 1521

38. Roberts MJ, Reich MR. Ethical analysis in public health. Lancet 2002; 359 1055-1059.

39. Alkire $S$, Chen L. Global health and moral values. The Trinity papers. Lancet 2004; 364: 1069-1074.

40. McMichael AJ, McKee M, Shkolnikov V, Valkonen T. Mortality trends and setbacks: global convergence or divergence? Lancet 2004; 363: 1155-1159,

41. Wiesel E. Without conscience. N Engl J Med 2005; 352:1 511-1513.

42. Lenin, Sobrannye Sochineniya (Collected Works), Edition 5, Vol 35, p. 68. Quoted in Solzhenitsyn A. The Gulag Archipelago 1918-1956. London: Collins and Harvill Press, 1974

43. Chang J, Halliday J. Mao. The Unknown Story. Jonathan Cape, 2005: 3.

44. Kapp C. Health and hunger in Zimbabwe. Lancet 2004; 364: 1569-1572.

45. Neibuhr R. Moral Man and Immoral Society. Charles Scribner \&t Sons, 1960: 207. (Initially published 1932.)

46. Neibuhr R. Moral Man and Immoral Society. Charles Scribner \& Sons, 1960: 14

47. Neibuhr R. Moral Man and Immoral Society. Charles Scribner \&t Sons, 1960: 117.

48. Ashworth $A$ Chopra M, MCCoy D et al. WHO guidelines for management of severe malnutrition in rural South African hospitals: effect on case fatality and the influence of operational factors. Lancet 2004; 363: 1110-1115.

49. Rowe AK, de Savigny D, Lanata CF, Victora CG. How can we achieve and maintain high-quality performance of health workers in low-resource settings? Lancet 2005; 366: 1026-1035.

50. English M, Esamai F, Wasunna A, et al. Assessment of inpatient paediatric care in first referral level hospitals in 13 districts in Kenya. Lancet 2004; 363: 19481953.

51. Dibetle M. Batho Pele, People First. Sick and tired of waiting. Mail and Guardian 2006; 13-19 January, p. 25

52. Tshabalala-Msimang M. The Star 23 September 2005. Quoted in an article by Phomelo Molwedi under the heading, 'I would not go to Baragwanath.'

53. Wachter RM. AIDS, activism, and the politics of health. N Eng/J Med 1992; 326 128-133.

54. Mthathi S, Mafu L, Geffen N, Gonyela M. Bullets and medicines in Queenstown. Equal Treatment 2005; Oct: 20

55. Our rights in our courts. Equal Treatment December 2005; Dec: 27.

56. Osborn JE. AIDS: Politics and science. N Engl J Med 1988; 318: 444-447.

57. Smetherham J-A. Cape Times 2004: 27 February.

58. Brueggemann W. The Prophetic Imagination. 2nd ed. Minneapolis: Augsburg Fortress, 2001: 40.

59. Neibuhr R. Moral Man and Immoral Society. Charles Scribner \& Sons, 1960: 258

60. Morris K. HIV murders prompt activist anger. Lancet 2000; 356: 840 .

61. Ainsworth $M$, Teokul W. Breaking the silence: setting realistic priorities for AIDS in less-developed countries. Lancet 2000; 356: 55-60.

62. Jewkes R, Levin J, Mbananga N, Bradshaw. Rape of girls in South Africa. Lancet 2002; 359: 319-320

63. Watts C, Zimmerman C. Violence against women: global scope and magnitude. Lancet 2002; 359: 1232-1237.

64. Bonhoeffer D. Ethics. SCM Press, 1955: 48. (Originally published in German in 1949.)

65. Bayer R. AIDS prevention - sexual ethics and responsibility. N Eng/ J Med 1996; 334: 1540-1542.

66. Bayer R. Public health policy and the AIDS epidemic: an end to HIV exceptionalism? N Eng/ J Med 1991; 324: 1500-1504.

67. Ramsay S. 'Shocking' AIDS data released in South Africa. Lancet 2001; 358 1345

68. Baleta A. Confusion over Mandela's 'support' of ANC HIV policy. Lancet 2002; 359: 855.

69. Susman E. US could learn from Cuban AIDS policy. Notes and Quotes. AIDS 2003: 17: N7-N8.

70. Hsieh $\mathrm{Y}-\mathrm{H}$, Chen CWS, Lee S-M, de Arazoza H. On the recent sharp increase in HIV detections in Cuba. AIDS 2001; 15: 426-428.

71. Frieden TR, Das-Douglas M, Kellerman SE, Henning KJ. Applying public health principles to the HIV epidemic. N Eng/ J Med 2005; 353: 2397-2402.

72. Kapp C. HIV overshadows South African health advances. Lancet 2004; 363 1202-1203.

73. Frank AW. The Renewal of Generosity. IIIness, Medicine and How to Live. London: University of Chicago Press, 2004: 29 